\title{
Postępy w badaniach nad gruźlicą od czasów Roberta Kocha do współczesności ${ }^{1}$
}

\section{Progress in the study of tuberculosis since Robert Koch to the present day}

\author{
Zofia Zwolska ${ }^{2}$
}

Warszawa

\begin{abstract}
Streszczenie: Artykuł ma charakter przeglądowy i przedstawia historię badań nad grúlica, w tym osiagnnięcia Roberta Kocha. Przypomniano także innych laureatów Nagrody Nobla, których prace dotyczyły gruźlicy: Wilhelma Roentgena, Tomasza Manna i Selmana Waksmana. Zarysowano kontekst kulturowy gruźlicy, choroby inspirującej wielu pisarzy, poetów, muzyków i malarzy. Szczegółowo omówiono udoskonalenia metod laboratoryjnych wprowadzone przez R. Kocha i jego współpracowników, zwłaszcza rozwój metod wybarwiania i wprowadzenie fotografii do bakteriologii. Odnotowano też niepowodzenia naukowe Kocha. Była nią tuberkulina, zagęszczony przesącz prątków hodowanych na bulionie z gliceryna, którą mylnie uznał za pomocną w walce $\mathrm{z}$ gruźlicą. Ponadto $\mathrm{w}$ artykule wykazano związki Roberta Kocha z Wolsztynem.
\end{abstract}

Abstract: This review article presents the history of investigation on tuberculosis starting from awarding the Nobel Prize to Robert Koch. Other Nobel Prize winners whose creativity was related to tuberculosis were also reminded. They were: Wilhelm Roentgen, Thomas Mann and Selman Waksman. The issue of cultural context of tuberculosis was raised because this disease inspired a lot of writers, poets, musicians, and painters. Improvements of lab methods made by Koch and his co-workers were discussed, especially the development of methods of staining and microbiologic photograph. Koch's failures with tuberculin, the thickened filtrate of mycobacteria cultured on bouillon with glycerin were taken into account as well. Moreover, links between Robert Koch and Wolsztyn were explained.

Słowa kluczowe: gruźlica, Robert Koch, Wolsztyn

Keywords: tuberculosis, Robert Koch, Wolsztyn

\section{Wstęp}

Wieloletnia praca Roberta Kocha nad poznaniem czynnika etiologicznego gruźlicy została uwieńczona w 1905 r. Nagrodą Nobla. Stało się to w 23 lata od pierwszej,

\footnotetext{
1 Artykuł stanowi rozszerzoną i recenzowaną wersję wykładu wygłoszonego 19 maja 2018 r. w Wolsztynie podczas konferencji pt. „Gruźlica - dawne doświadczenia, obecne osiagnięcia i zagrożenia”.

2 Instytut Gruźlicy i Chorób Płuc, Zakład Mikrobiologii, Warszawa ul. Płocka 26, e-mail: z.zwolska@igichp.edu.pl
} 
publicznej prezentacji w Berlińskim Towarzystwie Fizjologicznym, podczas której Robert Koch nie tylko wykładał, ale również prezentował rozmazy tkankowe pobrane od chorych na gruźlicę, barwione metoda, która później otrzymała nazwę Ziehl-Nelssona.

W śnieżny zimowy dzień 12 grudnia 1905 r. podczas uroczystości w Sztokholmie R. Koch wygłosił wykład pt. „O obecnym stanie walki z gruźlica”. Wykład laureata nie ograniczał się tylko do omówienia odkrycia czynnika etiologicznego gruźlicy, skupiał się także na metodach walki z gruźlicą. W prezentacji Koch nawiązał do innych uczonych, którzy pracowali nad etiologia gruźlicy, wskazał źródła transmisji prątków, omówił sytuację epidemiologiczna gruźlicy w kilku krajach europejskich proponując działania jakie należy podjać aby ograniczyć rozmiar choroby. Wskazał na konieczność propagowania oświaty zdrowotnej wśród ludzi zdrowych i chorych, konieczność popularyzacji wiedzy o chorobie, izolowaniu od otoczenia chorych na gruźlicę i profilaktykę. Jego wykład oceniany dzisiaj wydaje się bardzo nowoczesny, a zawarte w nim tezy słuszne. Koch bardzo optymistycznie patrzył na eradykacje gruźlicy, która miała rychło nastapićs.

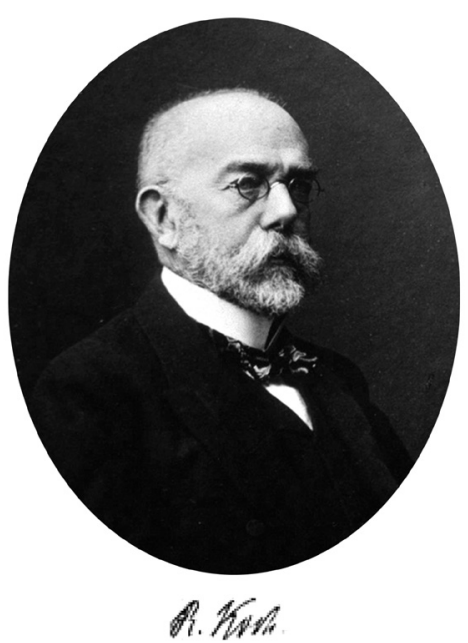

Ryc. 1. Robert Koch

(Muzeum Roberta Kocha w Wolsztynie)

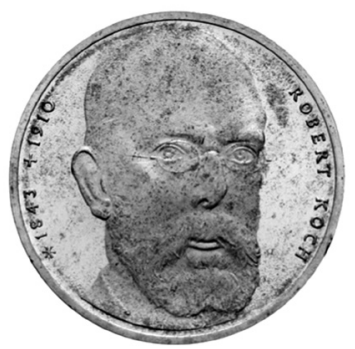

Ryc. 2. Pamiątkowa moneta (zbiory autorki)

Koch nie przewidywał, że prawie 140 lat po jego odkryciu gruźlica będzie nadal powodowała cierpienia wielu milionów ludzi na świecie. W końcu lat 1990-tych Światowa Organizacja Zdrowia ogłosiła powszechne zagrożenie świata gruźlica i choroba ta wspólnie z HIV i AIDS należy dzisiaj do największych zabójców ludzi. Zgony spo-

3 R. Koch, The Nobel lecture on how the fight against tuberculosis now stands, "Lancet" 1906, 1, s. 14491451. 
wodowane gruźlica zajmuja po HIV i AIDS drugie miejsce, zabijając każdego roku ponad 2 mln ludzi. Gruźlica nie tylko nie zniknęła z listy chorób społecznych, ale pokazała swoje „nowe oblicze”, którym stały się formy oporne na leki, wymagające niezwykle wysokich nakładów finansowych na leczenie. Pomimo, że szczepienia BCG, dostępne już od prawie 100 lat, radykalnie zmniejszyły zapadalność na gruźlicę szczególnie u dzieci i zapobiegają ciężkim jej postaciom u dorosłych, gruźlica jest ciagle problemem ogólnoświatowym ${ }^{4}$. Dostępna chemioterapia jest skuteczna, lecz wymaga wielu miesięcy leczenia 3-4 lekami równocześnie, a przypadkach form lekoopornych do leczenia stosuje się wiele leków przez wiele lat. Leczenie gruźlicy lekoopornej generuje bardzo wysokie koszty, którymi obciążone są budżety wszystkich państw, z założenia bowiem gruźlica jako choroba społeczna jest finansowana z budżetu państwowego ${ }^{5}$. Jednak w wielu ubogich krajach o dużym rozprzestrzenieniu się choroby oczekuje się, że pacjenci poniosą koszty jej leczenia, co skutkuje przerwami w leczeniu lub całkowitym jego brakiem. Powoduje to transmisję choroby do ludzi zdrowych i dalsze rozprzestrzenianie się choroby. Długie leczenie jest niezwykle uciążliwe dla chorych i wymaga monitorowania efektów ubocznych. Światowa epidemia narasta wraz z rozpowszechnianiem się wirusa HIV, wzrostem lekoopornych form z jej najgroźniejszymi postaciami pratkami MDR i XDR a wszechobecne niepokoje i konflikty wojenne w różnych krajach świata przyczyniają się do pogłębienia problemu. Najlepszym przykładem może być Ukraina, w której według raportu WHO liczba zachorowań na gruźlicę lekooporną typu MDR/XDR wzrosła w okresie konfliktu wojennego z 3482 (przed wojna) do 10585 w roku $2013^{6}$.

Niezwykle wysokich kosztów leczenia gruźlicy i długości jej leczenia nie można porównać do żadnej innej choroby zakaźnej, co doskonale obrazuje tabela 1.

Tabela 1. Średnie koszty leczenia gruźlicy w krajach europejskich w zależności od lekooporności Mycobacterium $^{7}$

\begin{tabular}{|l|l|c|}
\hline Typ lekooporności prątków gruźlicy & Czas leczenia & Koszty leczenia $\mathbf{1}$ chorego \\
\hline Prątki gruźlicy wrażliwe na leki & 6 miesięcy & $7800 €$ \\
\hline Prątki gruźlicy o oporności MDR & 24 miesiące lub dłużej? & $55000 €$ \\
\hline Prątki o oporności XDR & 99 miesięcy lub dłużej? & $180000 €$ \\
\hline
\end{tabular}

4 European Centre for Disease Prevention and Control/ WHO Regional Office for Europe, Tuberculosis surveillance and monitoring in Europe, Stockholm, Sweden: ECDC, 2016; World Health Organization. Global Tuberculosis report, 2015 WHO/HTM/TB/2015.22.Geneva, Switzerland, WHO, 2015.

5 R. Diel, J. Vandeputte, G. de Vries, J. Stillo, M. Wanlin, A. Nienhaus, Costs of tuberculosis disease in the European Union: a systematic analysis and cost calculation, "European Respiratory Journal" 2014, 43, s. 554565, DOI: 10.1183/09031936.00079413; T. Tanimura, E. Jaramillo, D. Weil, M. Raviglione, K. Lonnrath, Financial burden for tuberculosis patients in low-and middle-income countries: a systematic review, "European Respiratory Journal" 2014, 43, s. 1763-1775.

6 A. Dudnyk, O. Rzhepishevska, G. Kutsyna, K. Lange, Multidrug-resistant tuberculosis in Ukraine at the time of military conflict, "International Journal of Tuberculosis and Lung Diseases" 2015, 19 (4), s. 492-496.

7 R. Diel, J. Vandeputte, G. de Vries, J. Stillo, M. Wanlin, A. Nienhaus, Costs of tuberculosis disease... 
Czas trwania i skuteczność terapii potwierdzana jest metodami mikrobiologicznymi. Do wielu elementów, które powinny być brane pod uwagę przy prawidłowo prowadzonej walce z gruźlica, należy oczekiwanie na szczepionkę nowej generacji, która byłaby skuteczna w prewencji wszystkich postaci choroby, w tym lekoopornej, a także powinna zapobiegać aktywnej chorobie i latentnemu zakażeniu prątkami gruźlicy. Pozwoliłoby to zrealizować do 2050 r. plany WHO dotyczące globalnego zmniejszenia śmiertelności spowodowanej gruźlicą o 95\% i o 90\% zapadalności na gruźlicę ${ }^{8}$ Tymczasem prognozy odnośnie osiagnięcia założonych celów nie sa pomyślne. Autorzy artykułu pt. "Mission impossible: the end of TB strategy" stwierdzaja, że wyniki ich badań prowadzonych wspólnie z ekspertami WHO wskazuja: "that it is unrealistic to immagine that TB will be eliminated in the near future......"

\section{Inni laureaci Nagrody Nobla, których prace dotyczyły gruźlicy}

Opisując dokonania Roberta Koch w dziedzinie badań nad gruźlicą warto wspomnieć o innych laureatach Nagrody Nobla, których dokonania były powiązane z problematyką tej groźnej choroby zakaźnej. Szczególne wyróżnienia za odkrycia naukowe sa przyznawane od 1901 r. Pierwszym laureatem tej uznanej za najbardziej prestiżowa po dzień dzisiejszy nagrody naukowej - Nagrody Nobla odebranej z rąk króla Szwecji w 1901 r. za "odkrycie nowych promieni” był niemiecki uczony Wilhelm Konrad Roentgen (1845-1923). Wraz z dyplomem otrzymał nagrodę pieniężna, która wtedy wynosiła 150.800 koron szwedzkich (obecnie $10 \mathrm{mln}$ koron). Nagrodę i dyplom odebrał osobiście, chociaż nie wygłosił żadnego wykładu, jak to było w zwyczaju w następnych latach. Całą sumę noblista przekazał Uniwersytetowi w Wurzburgu, na którym studiował ${ }^{10}$.

W historii medycyny mało jest wielkich odkrywców, a tym bardziej laureatów Nagrody Nobla, których biogramy nie opisują konfliktów o palmę pierwszeństwa z innymi naukowcami, nie zawieraja plotek, a nawet skandali towarzyskich, osób, które małą wage przywiązują do zaszczytów i innych wyróżnień. Tą wyjątkowa postacia w historii wiekopomnych odkryć jest właśnie Wilhelm Konrad Roentgen, człowiek życzliwy innym, prostolinijny, bez żadnych widocznych wad. Odkrycie promieni $X$ (8 listopada 1895 r.) było kamieniem milowym w rozwoju medycyny a także światowej nauki. To drugie sformułowanie zostało potwierdzone przez uczestników ankiety, jaką w 2010 r. zorganizowało londyńskie Muzeum Nauki. Wśród 50.000 respondentów wybierajacych najważniejszy wynalazek w dziejach ludzkości najwięcej

8 N. Dalmia, A. J. Ramsay, Prime-boost approaches to tuberculosis vaccine development, "Expert Rev Vaccines" 2012, 14, s. 1221-1233; M. M. Usman, S. Ismail, T. C. Teoh, Vaccine research and development: tuberculosis as a global health threat, "Central European Journal of Immunology" 2017, 42(2), s. 196-204, DOI: 10.5114/ ceji.2017.69362. Epub 2017 Aug 8.

9 A. Dudnyk, O. Rzhepishevska, G. Kutsyna, K. Lange, Multidrug-resistant tuberculosis in Ukraine...

10 M. Urbanik, Odkrycie Roentgena - pierwsze doniesienia prasowe, artykuły naukowe i podręczniki w Krakowie. „Przegladd Lekarski" 2013/70/5 s 359-365; <https:/ / www.nobelprize.org/nobel_prizes/ physics/laureates /1901/ rontgen-bio.html> 
osób wskazało aparat rentgenowski ${ }^{11}$. Najważniejszą właściwościa promieniowania rentgenowskiego z punktu widzenia przydatności w medycynie jest jego przenikliwość. Trudno sobie dzisiaj wyobrazić współczesna medycynę bez możliwości zastosowania w różnych technikach obrazowych i terapeutycznych promieni jonizujących. W 1895 r. pojawiła się możliwość przejrzenia ciała ludzkiego na wskroś i zbadania prawie każdej jego części.

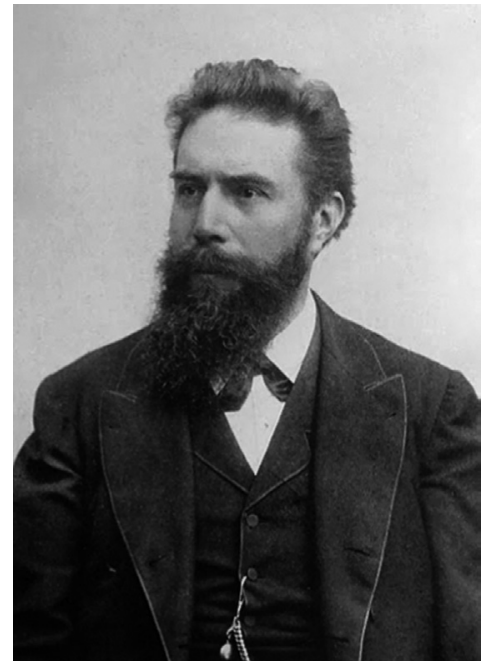

Ryc. 3. Wilhelm Rentgen (domena publiczna)

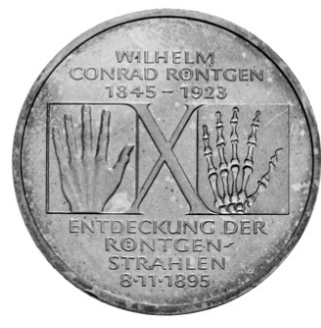

Ryc. 4. Moneta pamiątkowa (zbiory autorki)

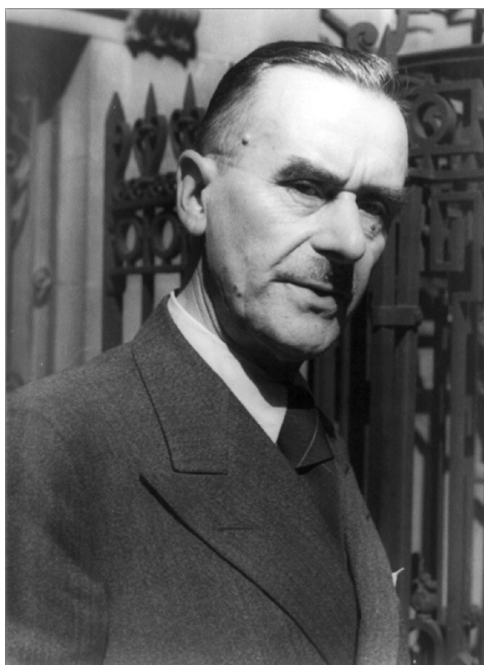

Ryc. 5. Tomasz Mann

(Fot.: Carl van Vechten, Van Vechten Collection, Library of Congress, domena publiczna)

Chronologicznie rzecz ujmując, kolejna nagroda Nobla (1929 r.), tym razem w dziedzinie literatury, przypadła w udziale Tomaszowi Mannowi (1875-1955) za powieść pt. „Czarodziejska góra” (der Zauberberg), w której autor opisuje w sposób nie tylko przejmujący, ale i barwny życie chorych na gruźlicę pacjentów sanatorium Berghof w Davos. Książka stanowi swoiste studium filozoficzne o chorowaniu i umieraniu ${ }^{12}$.

Selman Abraham Waksman amerykański mikrobiolog pochodzenia żydowskiego (1888-1973) otrzymał nagrodę Nobla w 1952 r. za odkrycie pierwszego leku do leczenia gruźlicy. Urodzony w guberni kijowskiej, po wyjeździe do USA wraz z uniwersyteckimi kolegami, w ramach projektu naukowego rozpoczął systematyczne poszukiwanie mikroorganizmów w glebie o potencjalnym działaniu przeciwbakteryjnym.

11 <http:/ / www.journal.doc.art.pl/pdf14/artbasedresearch_luczak_art_and_documentation14.pdf>

12 T. Mann, Czarodziejska góra, Warszawa 1972; S. Waksman, H. D. Woodruff, Actinomyces antibiotics, a new soil organism antagonistic to phatogenic and non-pathogenic bacteria, "Journal of Bacteriology" 1941, 42, s. 231-249. 


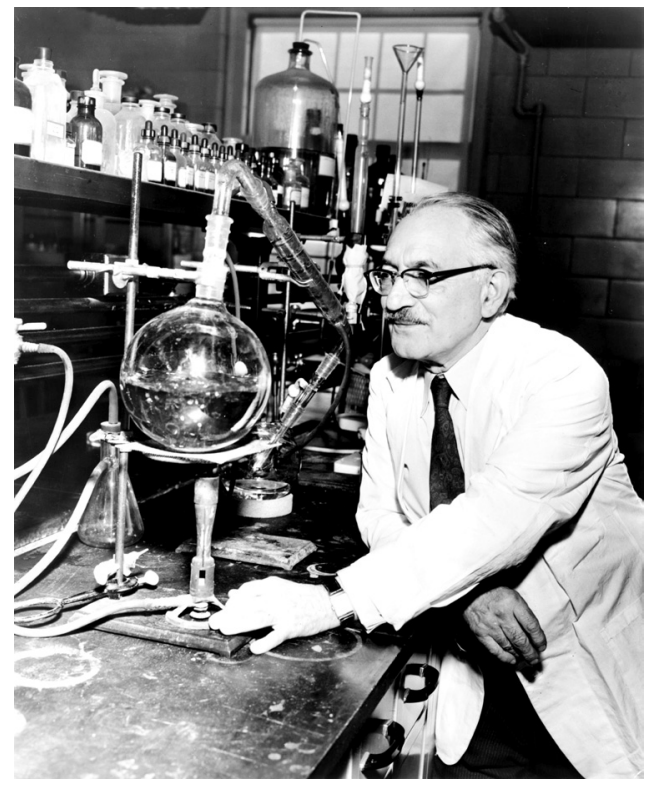

Ryc. 6. Selman A. Waksman

(Autor: New York World-Telegram and the Sun staff photographer: Roger Higgins, Library of Congress Prints and Photographs Division. New York World-Telegram and the Sun Newspaper Photograph Collection, domena publiczna)
W 1943 r. S. Waksman i jego asystent A. Schatz wyizolowali mikroorganizm, Strepotomyces griseus, który wytwarzał substancję o działaniu przeciwpratkowym ${ }^{13}$.

Często Waksman jest nazywany „Father of Anibiotics”, chociaż należy pamiętać, że wcześniej, w 1928 r., szkocki naukowiec i laureat Nagrody Nobla w 1945 r. Aleksander Fleming (1885-1955) odkrył całkiem przypadkowo penicylinę. Producentem penicyliny okazał się pędzlak nazwany Penicillium. $\mathrm{Na}$ zapomnianej przez naukowców i pozostawionej $\mathrm{w}$ laboratorium płytce Petriego z hodowla gronkowca złocistego wyrosła pleśń, która powodowała zahamowanie wzrostu Staphylococcus. Ta nieznana substancja była wydzielana przez Penicillum, który przypadkowo utworzył kolonie na płytce hodowlanej ${ }^{14}$. Należy przypomnieć, że 32 lata wcześniej francuski student medycyny Ernest Duchesne (1874-1912) zauważył

w laboratorium te same, specjalne właściwości pleśni ${ }^{15}$. Nie wyciagnał jednak żadnych wniosków i obserwacja została zapomniana. Godny przypomnienia jest fakt, że tysiące lat wcześniej starożytni Egipcjanie i Chińczycy obserwowali lecznicze działanie spleśniałego chleba i sojowych resztek i zalecali wcierać je w zakażoną skórę.

Wracając do tytułu „Father of Anibiotics”, być może przyznanie go jest związane z przypadkowościa odkrycia (jak u Fleminga) a nie z przemyślanym, zaplanowanym i systematycznie prowadzonym poszukiwaniem antybiotyku do leczenia najcięższych chorób zakaźnych (jak u Waksmana). Odbierając doktorat honoris causa na Uniwersytecie Harvarda, Fleming podkreślił rolę przypadku w karierze. Przekonywał, że „,badacz musi mieć swobodę w poszukiwaniach. Nadzorowanie pracy ze strony przełożonych i oczekiwanie szybkich rezultatów zabija kreatywność i twórcze myślenie"16.

13 J. H. Comroe Jr, Pay dirt: the story of streptomycin. Part II. Feldman and Hinshaw: Lehmann, "American Review Respiratory Disiseases" 1978, 117, s. 957-968.

141929 Penicillin discovered, < http:/ / www.history.com/this-day-in-history/ penicillin-discovered>

15 Ernest Duchesne and the concept of fungal antibiotic therapy $<w w w . t h e l a n c e t . c o m / j o u r n a l s /$ lancet /article/PIIS0140...>

${ }_{16}$ Cytat za: K. Kochman, Wynalazca z przypadku. <http://www.naukaonline.pl/nasze-teksty/nauki-biologiczne/item/108-wynalazca-z-przypadku.> 
Waksman, znawca mikrobiologii gleby, wraz ze swoimi kolegami i studentami przebadał około 10000 hodowli różnych mikrobów izolowanych z gleby i u około $10 \%$ z nich stwierdził aktywność przeciwbakteryjną. On też jest autorem nazwy „,antybiotyk" dla przeciwbakteryjnych substancji izolowanych z promieniowców i grzybów. W 1944 r. Waksman wspólnie z W. Feldmanem i H. C Hinshawem odkryli hamujące działanie streptomycyny na wirulentne prątki gruźlicy. Odbierając w 1952 r. Nagrodę Nobla w dziedzinie medycyny Selman Waksman przytoczył cytat z Eklezjastyka: "The Lord hath created medicines out of the earth and he that is wise will not abhor them". (Pan stworzył z ziemi lekarstwa, a człowiek mądry nie będzie nimi gardził", Mądrość Syracha 38) ${ }^{17}$.

Warto przytoczyć słowa Ludwika Pasteura: „szczęśliwy przypadek sprzyja tylko tym, którzy się mają na baczności”, w których uczony chciał podkreślić, jak ważne dla naukowca są obserwacje nawet błahych wyników, analizowanie ich i wnioskowanie. Historia odkrycia innego, niezwykłego antybiotyku do leczenia wielu infekcji Gram dodatnich i Gram ujemnych, przede wszystkim prątków gruźlicy, miała miejsce kilkanaście lat po odkryciach Waksmana. Miała ona swój początek latem 1957 r., gdy jeden z techników zatrudnionych w laboratoriach koncernu Dow-Lepetit Research laboratories w Mediolanie, spędzając letnie wakacje na francuskim Lazurowym Wybrzeżu pobrał kilka próbek gleby w pobliżu St. Raphael. Z ziemi tej wyizolowano nie znany dotąd gatunek bakterii z rodzaju Streptomyces, który nazwano Streptomyces mediterranei, później sklasyfikowany jako Nocardia mediterranei, a wytwarzane przez niego antybiotyki nazwano ryfamycynami. Pierwsze produkty fermentacji S. mediterranei zawierały mieszaninę wielu substancji działających przeciwbakteryjnie. Po licznych próbach udało się wyodrębnić ryfamycynę B w postaci krystalicznej i ryfamycynę SV, która została poddana próbom klinicznym. W 1965 r. przygotowano i wprowadzono do leczenia antybiotyk pod nazwą ryfampicyna (RMP), która pieszczotliwie nazwano Rififi. Od tamtej pory nie znaleziono drugiego tak aktywnie działającego przeciwpratkowo antybiotyku ${ }^{18}$.

Współcześnie trwaja próby badania aktywności przeciwpratkowej antybiotyku, znanego od dawna, z grupy spektynomycyn - spektynaminy, produkowanej przez Streptomyces spectabilis, Streptomyces flavosporiusi inne gatunki również izolowane z gleby. Pierwsze próby laboratoryjne i na zwierzętach wykazały zadawalająca aktywność przeciw Mycobacterium tuberculosis, brak krzyżowej oporności z innymi lekami przeciwgruźliczymi, wysoki margines bezpieczeństwa, niską toksyczność, bardzo dobry profil farmakologiczny i znaczną redukcję prątków gruźlicy w płucach zakażonych myszy, przedłużający czas ich przeżycia ${ }^{19}$.

17 F. L. Ayvazian, History of tuberculosis, [w:] L. B. Reichman \& E .S. Hershfield (red.), Tuberculosis: A Comprehensive International Approach, New York, 1993, s. 1-20.

18 G. Accocella, Clinical pharmacokinetics of rifampicin, "Clinical Pharmacokinetics" 1978, 3, s. 108-127; Z. Zwolska-Kwiek, Ryfampicyna, Warszawa 1989, s. 100.

19 R. H. Lee, J. G. Hurdle, J. Liu, D. F. Bruhn, T. Matt, Spectinamides: a new class of semisynthetic antituberculosis agents that overcome native drug efflux, "Natural Medicine" 2014, s. 152-158; Z. Zwolska, Improving treatment outcomes for tuberculosis, "Journal of Bioequivalence Availability" 2017, 9 (4), s. 442-446. 


\section{Gruźlica jako inspiracja twórczości artystycznej}

Gruźlica jako choroba była inspiracją twórczości wielu pisarzy, poetów, muzyków i malarzy. Jak wiemy, na przełomie XIX i XX w. wśród chorób zakaźnych nękających nie tylko Polskę, ale całą Europę, dominowała gruźlica. Stanowiła największe zagrożenie zdrowotne społeczeństw i była przyczyną zgonów głównie ludzi młodych pochodzących ze wszystkich warstw społecznych. Dokumenty opisujące epidemię gruźlicy w XIX w. są liczne i różnorodne. Są nimi opisy i naukowe prace lekarskie, pamiętniki chorych, życiorysy zmarłych, artykuły dziennikarskie, a nawet prace malarzy (np. „Krzyk” Muncha, autoportret Modiglianiego) i inne. W tym czasie endemia gruźlicy przerodziła się w epidemię. Tylu znakomitych ludzi, poetów, muzyków, pisarzy, aktorów - Balzac, Schubert, Goethe, Chopin, Mérimée, Chateaubriand i wielu innych - umarło na gruźlicę płuc w XIX w., że ich życiorysy można porównać do pedantycznie prowadzonych historii chorób. Ofiarami gruźlicy byli przede wszystkim ludzie młodzi. „Gruźlica zamieniała ich czas kochania na czas umierania”. Choroba wikłała losy wielu młodych ludzi, doprowadzając do ich śmierci ${ }^{20}$.

W XIX w. choroba gruźlicza zajmowała też znaczące miejsce w kulturze i sposobie wyrażania myśli romantycznej. Najczęstszą i najbardziej spektakularną postacia gruźlicy była jej postać płucna. Spotykamy ja wśród najbardziej znanych polskich rodzin: Mickiewiczów, Chopinów, Słowackich i Krasińskich. Chorowali w Europie znani artyści malarze, muzycy, a listy wysyłane do przyjaciół i rodziny stanowiły dokumentację cierpienia i przebiegu ich choroby. Fryderyk Chopin tak pisał z Majorki w 1838 r. do przyjaciela Fontany na temat konsylium miejscowych:

Jeden z nich kręcił nosem, kiedy kasłałem, drugi przykładał obie ręce do klatki piersiowej, trzeci opukiwał i osłuchiwał mnie. Podczas gdy pierwszy tłumaczył, że umrę, drugi mówił, że umieram, a trzeci, najdowcipniejszy, że już umarłem. Istotnie czuje się źle i wegetuję jak pies ${ }^{21}$.

Po każdym przyjeździe Chopina do Paryża, gdy zdrowie ulegało pogorszeniu, jedna z uczennic zanotowała w pamiętniku:

Chopin jest blady, osłabiony, kaszlący, zażywa często opium w cukrze wraz z woda gumową i wciera w czoło wodę kolońska, pomimo widocznego zmęczenia uczy swoich adeptów gry z cierpliwością i wytrwałością...22.

W Bibliotece Polskiej w Paryżu znajduje się unikatowy zbiór zapisków lekarskich dotyczących pacjentów zgłaszających się do leczenia ambulatoryjnego po dwudziestu latach przebywania na uchodźstwie. Smutna to lektura.... ${ }^{23}$.

20 T. Kielanowski, Elementy etiopatologii gruźlicy człowieka, Warszawa 1965; B. Zaorska, Ich mizeria tułacza z gruźlica w tle, Warszawa 1998.

${ }_{21}$ Cytat za: B. Zaorska, Śladami lekarzy - polskich uchodźców popowstaniowych w XIX wieku, Warszawa 1996.

22 Tamże.

23 B. Zaorska, Odnaleziony zbiór kart ambulatoryjnych z roku 1849 i 1850 dotyczacy grupy uchodźców polskich w Anglii, „Archiwum Historii i Filozofii Medycyny” 1997, s. 211-218. 


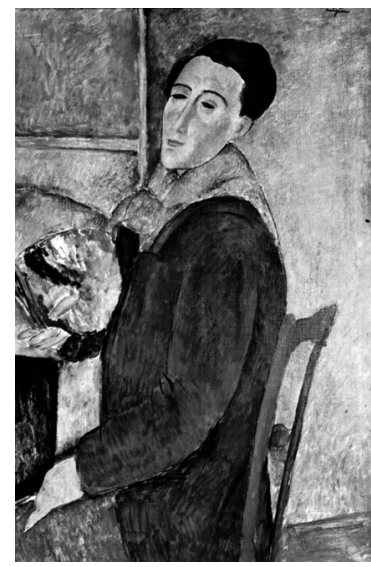

Ryc. 7. Amedeo Modigliani (autoportret, domena publiczna)

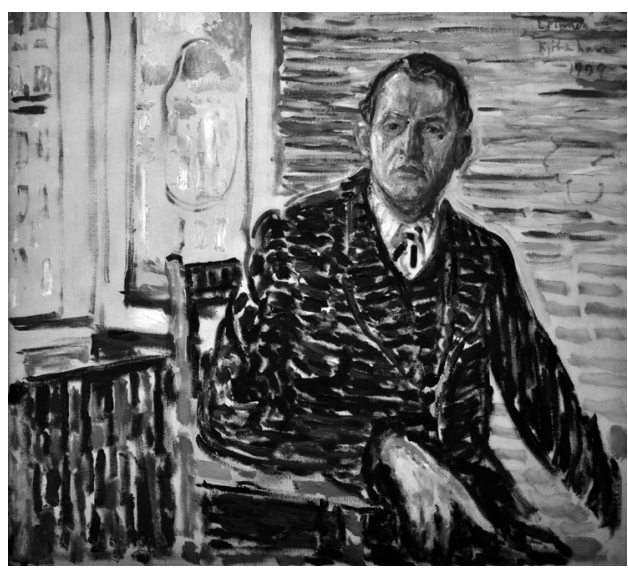

Ryc. 8. Edvard Munch

(autoportret w klinice, domena publiczna)

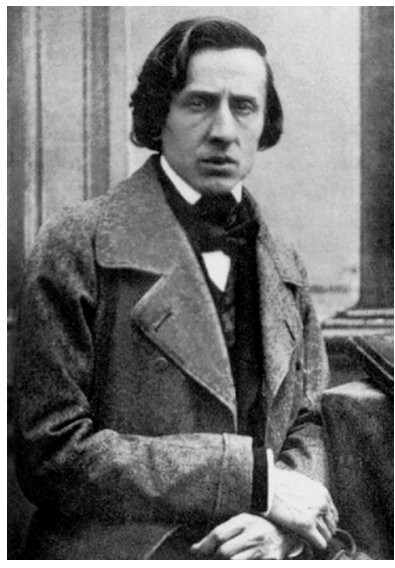

Ryc. 9. Fryderyk Chopin w 1849 r. (fot. Louis-Auguste Bisson, domena publiczna)

Susan Sontag (1933-2004) amerykańska pisarka w książce „Illness as Metaphor” pisała:

Gruźlica jest nocna półkulą życia, naszym najbardziej uciażliwym obywatelstwem. (...) Gruźlica czyni ciało przeźroczystym. Od najwcześniejszych stadiów obfituje w symptomy - stopniowy uwiąd ciała, kaszel, ospałość, goraczkę. (...) Gruźlica jest dezintegracja, roztopieniem w goraczce, dematerializacja; jest choroba płynów - ciało zmienia się we flegmę, śluz, plwocinę i ostatecznie w krew. Wiele jej symptomów ma charakter zwodniczy - ożywienie jest skutkiem osłabienia, zaróżowione policzki są wynikiem goraczki, nagły przypływ sił witalnych oznaką zbliżającej się śmierci... ${ }^{24}$.

\section{Prace Roberta Kocha nad udoskonaleniem technik laboratoryjnych}

Koch rozpoczynał prace nad etiologia gruźlicy już jako doświadczony naukowiec. Miał za soba pomyślnie prowadzone i zakończone sukcesem prace nad zakażeniami przyrannymi leczonymi u żołnierzy na wojnie francusko-pruskiej, zdobył umiejętność mikroskopowania, fotografowania bakterii i rysowania obrazów oglądanych pod mikroskopem. Wprowadził do badań zwierzęta laboratoryjne wywołując u nich w warunkach eksperymentalnych określona chorobę $e^{25}$. Dotyczyło to początkowo bakterii waglika Bacillus anthracis nad którym badania rozpoczął na początku swojej kariery naukowej ${ }^{26}$. Pomimo, że czynnik etiologiczny waglika odkrył francuski weterynarz Pierre Rayer ( 1793-1867), a w kilka lat później Franz Antoine Pollender (1800-1879)

\footnotetext{
24 S. Sontag, Choroba jako metafora, Warszawa 1999.

25 Z. Zwolska, Robert Koch twórca bakteriologii chorób zakaźnych, Gdańsk 2006.

26 R. Koch, Etiologia zachorowań na waglik (1876), Poznań - Wolsztyn 1996.
} 
i Casimir-Joseph Davaine (1812-1882), to dopiero R. Koch odkrył pełny cykl życiowy bakterii zdolnej do wytwarzania form przetrwalnikowych. Oglądał pod mikroskopem skrawki tkanek pobranych od chorych zwierzat, wykonywał zdjęcia, a nawet rysunki. Pracował systematycznie i pragmatycznie, zawsze stosując jako materiał kontrolny zdrowe tkanki.

Kolejnym zamysłem Kocha było prowadzenie badań in vitro, poza normalnymi warunkami makroustroju. Do tego typu hodowli mikroorganizmów potrzebne były odpowiednie warunki biochemiczne, głównie pożywki inkubacyjne.

Do eksperymentów, które zasługują na opisanie, należało pobranie z komory oka wołu drobnej ilość płynu i zakażenie go skrawkiem tkanki pobranej ze śledziony padłej na waglika myszy. Tę płynną hodowlę umieścił Koch pomiędzy dwoma szklanymi płytkami, jedna z wgłębieniem (odpowiadało to „szkiełku z łezka” używanej współcześnie), i zbudowanej przez siebie prostej cieplarce ogrzewanej za pomoca lampki naftowej. Doświadczenie powiodło się tylko częściowo, ponieważ hodowla została zanieczyszczona wieloma różnymi gatunkami bakterii znajdującymi się w otoczeniu. Koch starał się znaleźć sposób na wyeliminowanie przypadkowych zanieczyszczeń i otrzymanie czystej monokultury bakterii. Wkrótce osiagnał takie warunki w tzw. „kropli wiszącej”. Hodowla była izolowana przed kontaminacją z zewnątrz i rozwijały się w niej tylko bakterie waglika. Kochowi - jako pierwszemu - udało się tą metoda uzyskać czystą hodowlę bakteryjną. Należy dodać, że metoda ta jest znana w mikrobiologii do dzisiaj.

Kolejnym przełomowym etapem pracy mikrobiologicznej było zastosowanie stałych pożywek inkubacyjnych, które umożliwiały rozróżnienie i izolowanie różnych gatunków bakterii. Początkowo Koch pobierał niewielkie objętości płynnych hodowli i umieszczał je na plastrach ugotowanego ziemniaka otrzymując pojedyncze kolonie bakterii. Inkubacje prowadził w szklanych, zamykanych słojach ${ }^{27}$.

\section{Prace w laboratorium nad czystymi kulturami bakterii}

Na początku 1880 r. Koch otrzymał propozycję objęcia prestiżowego stanowiska w Berlinie i wkrótce powołano go na stanowisko radcy stanu i członka rzeczywistego Cesarskiego Urzędu Zdrowia. Z tytułem lekarza rządowego otrzymał małe laboratorium i pierwszych asystentów. Byli to dwaj lekarze wojskowi: Gregor Gaffky (1850-1918), który wspólnie z Kochem pierwszy wyizolował Vibrio cholerae oraz czystą hodowlę Salmonella typhi oraz Fridrich Löffler (1852-1915) odkrywca Corynebacterium diphterie, po raz pierwszy opisał zarazek grypy, wspólnie z Frochem wykrył zarazek nosacizny i różycy. Do głównych zadań zespołu, który stopniowo poszerzał się o nowych asystentów należało rozwijanie technik izolacji i hodowania bakterii patogennych, zbieranie danych bakteriologicznych i ustalanie priorytetów w higienie i zdrowiu publicznym Niemiec. Robert Koch wykształcił wielu znakomitych naukowców-bakteriologów, których osiagnięcia wpłynęły na poznanie i zrozumienie wielu 
zjawisk w medycynie człowieka. Niektórzy spośród przyjaciół, współpracowników i uczniów Roberta Kocha zostali uhonorowani Nagrodą Nobla.

Jednym z nich był Julius Richard Petri (1852-1921). Jego badania były ściśle związane z poszukiwaniem odpowiednich metod do hodowania bakterii. Pracujacc w laboratorium Kocha w Berlinie zaproponował do inkubacji bakterii na pożywce płytkę własnego pomysłu, która przetrwała do dzisiaj i nosi nazwę jego odkrywcy - płytki (szalki) Petriego. Do czasu wykrycia płytki bakterie inkubowano pod szklanymi kloszami. Od tamtej pory płytka Petriego stanowi codzienne wyposażenie każdego laboratorium mikrobiologicznego na świecie służąc badaniom diagnostycznym i naukowym. Jest znana uczniom, studentom i naukowcom.

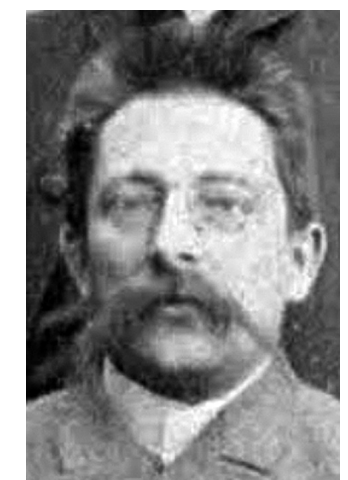

Ryc. 10. Julius Richard Petri (domena publiczna)

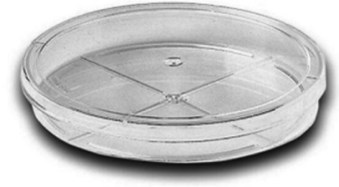

Ryc. 11. Płytka Petriego (fot. autorki)

J. R. Petri urodził się w 1852 r. w Bermen koło Wuppertalu. Pochodził z rodziny znakomitych uczonych. Jego dziadkowie, ojciec oraz kuzyni byli profesorami wielu specjalności na różnych niemieckich uczelniach. W latach 1871-1875 ukończył Cesarską Akademię dla lekarzy wojskowych. Praktykę lekarską rozpoczął jako zastępca ordynatora w berlińskim szpitalu Charitè. W 1976 r. obronił doktorat na podstawie pracy „The chemistry of protein urine tests”. Pracując w Cesarskim Biurze Ochrony Zdrowia w Berlinie spotkał Roberta Kocha i jego zainteresowania skierowały się w stronę bakteriologii. Wkrótce potem rozpoczał pracę w laboratorium Kocha i bardzo prędko zetknął się z wieloma, na pozór błahymi problemami techniki laboratoryjnej. Do głównych należała hodowla mikroorganizmów, do której brakowało odpowiednich naczyń. Wtedy w laboratoriach używano dużych, szklanych naczyń, które przykrywano płytami lub kloszami. Petri zaproponował do inkubacji bakterii płytkę (szalkę) własnego pomysłu, którą można było napełnić pożywką hodowlaną.

W pracach nad izolacja czystych kultur niezwykle pomocna była młoda asystentka urodzona w Nowym Jorku, pochodząca z bogatej rodziny holenderskich imigrantów, Fanny Angelina Eilshemius (1850-1934). Jako młoda dziewczyna przyjechała do Europy, gdzie spotkała i poślubiła niemieckiego lekarza Walthera Hesse. Doktor Hesse zainteresowany badaniami na polu mikrobiologii chorób zakaźnych rozpoczął wraz 
z żoną pracę w laboratorium Kocha. Kolejnym problemem technicznym, który nastręczał wiele trudności przy hodowaniu bakterii była żelatyna, znana jako jedyny czynnik zestalający pożywki. Pod wpływem wysokiej temperatury powietrza w laboratorium i wzrostu bakterii proteolitycznych żelatyna rozpuszczała się uniemożliwiając dalszą hodowlę. Lina Hesse przypomniała, że w krajach tropikalnych do zestalenia deserów używa się kompleksu polisacharydowego z agar-agar izolowanego z morskich wodorostów. Państwo Hesse zaproponowali R. Kochowi zamianę żelatyny na agar, który stał się znakomitym składnikiem pożywek mikrobiologicznych. Był nietoksyczny dla bakterii i innych żywych organizmów, fizjologicznie obojętny, rozpuszczał się $\mathrm{w} 100^{\circ} \mathrm{C}$, zestalał $\mathrm{w} 45^{\circ} \mathrm{C}$, mógł być poddawany procesom sterylizacji. Tak więc składniki używane do przygotowaniu potraw w kuchni zrewolucjonizowały techniki mikrobiologiczne, a ich zastosowanie pozwoliło hodować i izolować bakterie. Jak dotąd niewiele kobiet odegrało znaczącą rolę $\mathrm{w}$ odkryciach mikrobiologicznych, jednak to, bezsprzecznie przełomowe, było dziełem kobiety. Metoda hodowania na pożywkach agarowych jest używana do dzisiaj we wszystkich laboratoriach świata. Mikrobiolodzy mieli więc już do dyspozycji gotowe narzędzie do hodowania i izolowania różnych gatunków bakterii - płytkę Petriego z pożywkami zestalonymi agarem ${ }^{28}$.

W latach 1882-1885, po opuszczeniu laboratorium Kocha, R. Petri otrzymał stanowisko ordynatora w sanatorium dla chorych na gruźlicę w Görbersdorf w Sudetach (niedaleko Wałbrzycha). Sanatorium w Görbersdorf zostało uruchomione przez dr Hermanna Brehmera (1826-1889), w połowie Polaka, syna ślązaczki nazwiskiem Każecka ${ }^{29}$. Było to pierwsze na świecie specjalistyczne sanatorium dla chorych na gruźlicę, w którym zastosowano nowatorską metodę leczenia klimatyczno-dietetycznego. Na wzór sanatorium w Görbersdorf został stworzony ośrodek leczenia gruźlicy w Davos. Kolejno otwierano sanatoria $w$ innych krajach europejskich, $w$ tym $w$ Polsce i w USA.

Doktor R. Petri niezależnie o innowacyjnych pomysłów w pracy laboratoryjnej opublikował prawie 150 prac na temat higieny i bakteriologii oraz wspólnie z Hermannem Brehmerem podręcznik na temat etiologii terapii przewlekłej gruźlicy płuc. Zmarł w Zeitz w 1921 r. w wieku 69 lat ${ }^{30}$.

W późniejszym czasie sanatorium w Görbersdorf zyskało miano „śląskiego Davos”. Bliskim współpracownikiem dyrektora dr Hermana Brehmera stał się jeden z najwybitniejszych polskich lekarzy przełomu XIX i XX w. polski pulmonolog prof. Alfred Sokołowski (1850-1924). Dla uczczenia jego zasług w 1945 r. miejscowości sanatoryjnej nadano jego imię (od 1945 r. Sokołowsko, 540-600 m n.p.m.).Sanatorium jest czynne do dzisiaj ${ }^{31}$.

28 Z. Zwolska, Robert Koch twórca...

29 M. Migała, Rys historyczny rozwoju leczenia gruźlicy na Górnym Śląsku w drugiej połowie XIX i pierwszej połowie XX wieku, [w:] Walka z gruźlicq u ludzi i zwierząt w Polsce, red. H. Dusińska i Z. Zwolska, Warszawa 2012.

$30<$ http:/ / thebiomedicalscientist.net/science/big-story-petri-dish>.

31 T. M. Daniel, Hermann Brehmer and the origins of tuberculosis sanatoria, "International Journal of Tuberculosis and Lung Diseases" 2011, 15, s. 161-162; Z. Zwolska, Historia rozwoju mikrobiologicznej diagnostyki gruźlicy w Polsce, [w:] Rudka 100 lat w stużbie zdrowia, red. H. Dusińska, J. B. Gliński, M. Zambrzycka, Warszawa 2008, s. 22-34. 


\section{Barwienie prątków gruźlicy. Prace zespołu Koch-Ehrich-Ziehl-Neelsen. Postulaty Kocha}

Trzej kolejni współpracownicy R. Kocha: Paul Ehrlich, Franz Ziehl i Friedrich Carl Adolf Neelsen, chociaż nie pracowali w jego laboratorium, odegrali doniosłą rolę w pracy nad barwieniem prątków gruźlicy. Paul Ehrlich (1854-1915), którego uważa się za twórcę immunologii, laureat Nagrody Nobla, zajmował się ponad to barwieniem tkanek i poszukiwaniem leków. Wszystkie pola działania zaowocowały wielkimi odkryciami. Urodził się na Dolnym Śląsku w Strehlend (obecnie Strzelin), ukończył celująco gimnazjum we Wrocławiu, studiował medycynę we Wrocławiu i Strasburgu, obronił doktorat na Uniwersytecie w Lipsku praca związaną z różnicowaniem zabarwionych tkanek. Podczas studiów we Wrocławiu spotkał po raz pierwszy Roberta Kocha i od tej pory datuje się zażyłość obu uczonych.

Historia barwienia prątków gruźlicy ma swój poczatek wraz z odkryciem Kocha i pierwszą prezentacją 24 marca 1882 r. Koch szczegółowo opisał przygotowanie rozmazów na szkiełkach, ich suszenie, utrwalanie i barwienie. Nie było to jednak barwienie różnicujące. Metoda barwienia pratków gruźlicy opierała się na trzech głównych zasadach: użycie chemicznych barwników, które mogą wnikać do komórek zabitych bakterii, podgrzewanie preparatu i odbarwianie. W swoim wykładzie Koch zawarł z precyzyjną dokładnością wszystkie szczegóły techniczne dotychczasowego sposobu barwienia, przygotowanie odczynników, czas ich działania, temperaturę podgrzewania i inne. Przyszła pora na udoskonalenie obrazu mikroskopowego.

W pierwszych rozmazach Kocha pratki były widoczne w mikroskopie jako cienkie, bladoniebieskie laseczki. Działo się to za sprawą błękitu metylenowego na podbarwionym, wezuwina (brąz Bismarcka) brązowym tle. Niestety, niebieski barwnik zabarwiał nie tylko prątki gruźlicy również inne gatunki bakterii. Barwienie wymagało kilkunastu godzin. Wkrótce udało się Ehrlichowi udoskonalić sposób barwienia, odkrywając cechę kwasooporności prątków. Ehrlich barwił rozmazy błękitem metylenowym, następnie kapał je w rozcieńczonych kwasach. Ten sposób doprowadził od odbarwionego tła, natomiast pratki zachowały uprzednią barwę. W dalszych próbach Ehrlich zastapił błękit metylenowy fuksyną anilinową. W tym miejscu należy dodać, że Ehrlich do poszukiwań sposobów barwienia użył swojej własnej plwociny i pewnego dnia zauważył w niej tysiące komórek prątków gruźlicy. Był poważnie chory na gruźlicę, o której wcześniej nie wiedział. Sam zdiagnozował u siebie gruźlicę i zdecydował się na leczenie klimatyczne w ciepłych krajach. Dwuletni pobyt w Egipcie uzdrowił Ehrlicha.

Do dalszego udoskonalenia techniki barwienia prątków przyczynili się dwaj niemieccy lekarze: Franz Ziehl i Friedrich Carl Adolf Neelsen. Ziehl działał na rozmaz roztworem fioletu, a następnie odbarwiał go mieszanina alkoholu i kwasu solnego i podbarwiał błękitem metylenowym. Powodowało to, że fioletowe prątki wyraźnie odbijały się od niebieskiego tła. Kolejno Neelsen zamienił fiolet na fuksynę karbolowa, która zabarwiała prątki na czerwono. Połączenie tych sposobów stworzyło różnicującą metodę stosowaną do dzisiaj. Nosi ona nazwę metody Ziehla-Neelsena (Z-N) lub w skrócie AFB (ang. acid fast bacilli), i jest używana we wszystkich laboratoriach 
prątka na świecie. Do tej pory stanowi jedną z najważniejszych metod w diagnostyce gruźlicy. Jest też klinicznym wskaźnikiem intensywności prątkowania chorego oraz postępów w leczeniu choroby.

W literaturze naukowej niezliczona ilość publikacji opisuje przydatność rozmazów barwionych według metody Ziehla-Neelsena. Podziw budzi ogromna praca, jaką czterej badacze wykonali zaledwie $\mathrm{w}$ jeden rok a pierwsza publikacja ukazała się 12 sierpnia 1882 roku, to jest w pięć miesięcy po słynnej prezentacji Kocha o wykryciu prątków gruźlicy ${ }^{32}$.

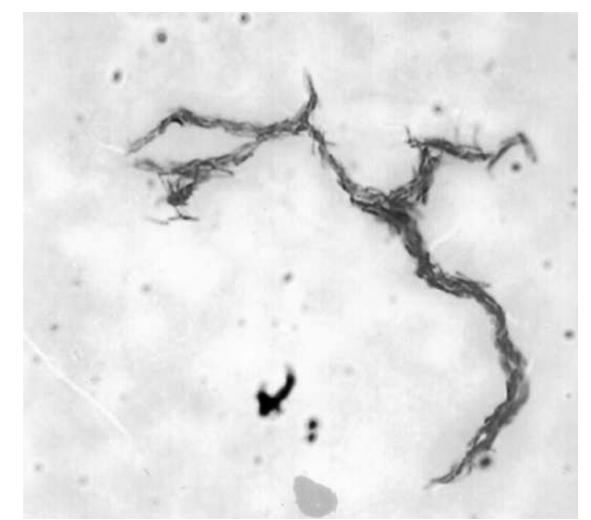

Ryc. 12. Prątki gruźlicy zabarwione metodą Ziehl-Neelsona (fot. autorki)

Już w następnym roku Franz Ziehl opisał przypadki znalezienia prątków w rozmazach wykonanych z plwocin pobranych od 73 chorych podejrzanych o gruźlicę. Wnioski z jego badań brzmią bardzo współcześnie:

1. w większości przypadków gruźlicy płuc w rozmazach mikroskopowych plwociny można znaleźć prątki; mogą zdarzyć się również rozmazy ujemne;

2. wykazanie pratków w rozmazach stanowi potwierdzenie gruźlicy, jednak w niektórych przypadkach konieczna jest dalsza diagnostyka różnicowa;

3. nie znalezienie prątków $\mathrm{w}$ rozmazach nie wyklucza gruźlicy;

4. liczba i rodzaj prątków w rozmazach nie stanowią żadnej podstawy prognostycznej.

Badania Kocha jako lekarza i bakteriologa nad waglikiem oraz innymi chorobami dały pierwszy, prawdziwy dowód na związek zakażenia bakteriami patogennymi z konkretnym schorzeniem. Doświadczenia umożliwiły sformułowanie zasad laboratoryjnego diagnozowania chorób zakaźnych i noszą nazwę „postulatów Kocha”. Bakterie można uznać za czynnik przyczynowy choroby, jeżeli spełnione zostaną cztery warunki: 
1. powinno się je znaleźć w każdym przypadku choroby,

2. posiane na pożywkach powinny wyrastać w postaci czystych kolonii,

3. określoną chorobę,

4. materiał pobrany ze zmian w narządach chorych zwierzat i posiany na pożywki musi dawać czyste kolonie tego samego gatunku bakterii.

Formułujac postulaty Koch wskazał, jak wiele działań należy wykonać w laboratorium, aby zdiagnozować chorobę zakaźna. Postępując według tych zasad możemy uznać dany gatunek bakterii za czynnik przyczynowy choroby ${ }^{33}$. Jako zwierzęta eksperymentalne używano kilku gatunków gryzoni i małych ssaków, a przede wszystkim świnkę morską wprowadzoną nota bene przez R. Kocha.

Świnka morska przez wiele dziesięcioleci XX w. była doskonałym medium do diagnozowania różnych postaci gruźlicy szczególnie postaci skąpo prattkowych np. z materiałów pobranych od dzieci, lub w przypadkach podejrzenia o gruźlicę pozapłucna. Stosowano ją w różnych laboratoriach mikrobiologii gruźlicy na świecie aż do chwili wprowadzenia automatycznych systemów hodowlanych typu Bactec. Od czasów Kocha metody mikrobiologiczne stanowią złoty standard w diagnostyce, a wykrycie prątków jest metodą rozstrzygającą o gruźlicy.

Należy dodać, że czynnik etiologiczny trądu Mycobacterium leprae powodujacy cierpienia milionów ludzi na świecie, wykryty przez Armauera Hansena (1841-1912) wcześniej niż pratek gruźlicy, nie wypełnia po dziś dzień postulatów Kocha. Jak dotąd nie udało się żadnemu badaczowi wyhodować prątków trądu poza organizmem żywym. Główne badanie diagnostyczne w trądzie odbywają się przy użyciu testów genetycznych i w próbie biologicznej na myszach i pancernikach ${ }^{34}$. Poza trądem, niektóre inne choroby zakaźne, w tym szczególnie rozprzestrzeniające się przez wirusy jako struktury subkomórkowe niezdolne do rozmnażania się poza komórkami gospodarza, nie wypełniają również postulatów Kocha. Obecnie, gdy rozwinęła się genetyka bakterii i poznano genom wielu gatunków mikroorganizmów, w tym również Mycobacterium tuberculosis i Mycobacterium leprae, cztery postulaty Kocha zostały wzbogacone przez metody molekularne. W XXI w. w diagnostyce chorób zakaźnych nadal respektujemy wszystkie cztery postulaty dodając do nich kolejny, który brzmi: wykrycie materiału genetycznego (DNA lub RNA) mikroorganizmu może stanowić potwierdzenie choroby ${ }^{35}$.

\section{Fotografowanie bakterii}

Przyjmuje się, że Koch pierwszy wprowadził fotografię do prezentowania bakterii, ich różnych form i postaci. Planował nawet przygotować książkę z fotografiami

33 Tamże.

34 Z. Zwolska, E. Augustynowicz-Kopeć, Trąd jedna z zapomnianych chorób tropikalnych, „Postępy Higieny i Epidemiologii" 2017, 71, s. 69-77.

35 T. P. Honap, L. A. Pfister, G. Housman, S. Mills, R. P. Tarara i wsp., Mycobacterium leprae genomes from naturally infected nonhuman primates, 2018, <https:/ / doi.org/10.1371/journal.pntd.0006190>; G. Satta, A. Atzeni, T. D. McHugh, Mycobacterium tuberculosis and whole genome sequencing: a practical guide and online tools available for the clinical microbiologist, "Clinical Microbiology and Infection" 2017, s. 69-72. 
bakterii, która mogłaby być pomocna przy wykrywaniu i różnicowaniu ich gatunków. Niestety, plan ten nie został zrealizowany. Pod koniec 1876 r. Koch zaproponował użycie odbitki zamiast fotolitografii. Dokonał kilku ulepszeń w mikrofotografii poprzez zmiany $\mathrm{w}$ budowie aparatu, ulepszenie mikroskopu świetlnego i technikę wykonywania odbitek. W 1900 r. w Instytucie Chorób Zakaźnych w Berlinie otworzył pracownię, w której rozwijano różne techniki fotograficzne. Od tamtego roku Instytut dokumentuje prace i posiada bogata kolekcję fotograficzna. Dokonania Kocha w dziedzinie dokumentacji fotograficznej dały podwaliny nowoczesnej mikrobiologii, która $\mathrm{w}$ pełni rozwinęła się $\mathrm{w} X X \mathrm{~W} .{ }^{36}$.

\section{Poszukiwanie leku przeciwprątkowego. Tuberkulina}

Po wielu sukcesach w identyfikacji chorób zakaźnych i odkryciu czynnika etiologicznego gruźlicy cały świat oczekiwał na lek przeciwpratkowy. W 1890 r. Koch rozpoczał prace, które doprowadziły do uzyskania tuberkuliny. Stanowiła zagęszczony przesącz prątków hodowanych na bulionie z gliceryna. Nie wiadomo, jakimi przesłankami kierował się w przypuszczeniu, że jest to właściwa droga do odkrycia leku. Wstępne wyniki prowadzone na zwierzętach i obserwacje kliniczne chorych były tak obiecujące, że rozpoczęto produkcję tuberkuliny na szerszą skalę i otwarto w Berlinie oddział leczenia chorych na gruźlicę.

W krótkim czasie okazało się, że tuberkulina nie spełniła pokładanych w niej nadziei i rozczarowała zarówno lekarzy jak i chorych. W prasie fachowej ukazywały się artykuły krytykujące Kocha za propagowanie tajnego, niebezpiecznego leku. Te wyniki były wielkim rozgoryczeniem, ale doprowadziły Kocha do zmiany pogladów na temat leczniczej roli tuberkuliny. Znalazła ona jednak zastosowanie jako test diagnostyczny stosowany powszechnie do dzisiaj. Pierwszymi, którzy zastosowali tuberkulinę do testów skórnych byli: C. Pirquet, C. Mantoux, E. Moro i A. Wolf-Eisner ${ }^{37}$.

\section{Wolsztyn - szczególne miejsce w życiu i pracy naukowej Roberta Kocha}

Robert Koch stanowi dla Polaków szczególnie bliską postać, ponieważ pracę naukową rozpoczął w Wolsztynie koło Poznania, gdzie równocześnie był lekarzem polskiej ludności. Nawet wtedy, gdy był u szczytu sławy, nazywano go często „doktorem z Wolsztyna". Pierwsza samodzielna praca naukowa i szersza praktyka lekarska uczonego rozpoczęła się właśnie w Wielkopolsce. I chociaż w tamtych czasach zarówno Wolsztyn, jak cała Wielkopolska, należał administracyjnie do zaboru pruskiego to

36 S. M. Blevins, M. S. Bronze, Robert Koch and the "golden age" of bacteriology, "International Journal of Infectious Diseases" 2010, 14, s. e744-e751.

${ }_{37}$ M. M. Madkour, K. E. Al.- Otaibi, R. Al-Swailen, Historical Aspects of tuberculosis, [w:] Tuberculosis, red. M. M. Madkur, Berlin - Heidelberg 2004; H. Yang H, N. A. Kruh-Garcia, K. M. Dobos, Purified protein derivatives of tuberculin--past, present, and future. "FEMS Immunol Med Microbiol." 2012 Dec; 66(3), s. 73-80. 


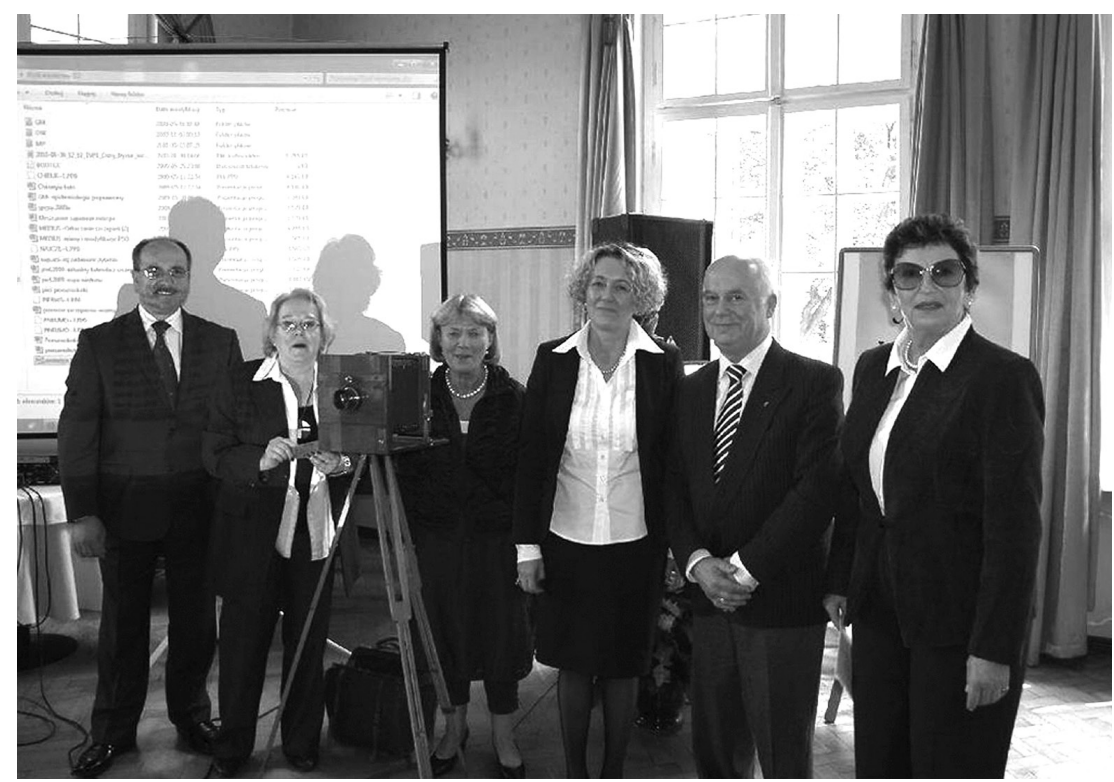

Ryc. 13. Uczestnicy jednej z konferencji w Wolsztynie, wśród nich prawnuk Roberta Kocha - Wolfgang Pfhul (drugi z prawej, fot. autorki)

chorzy, których leczył, byli narodowości polskiej, i warunki, w których pracował były odległe od tych, jakie panowały w krajach zachodniej części Europy ${ }^{38}$.

Praca w polskim środowisku umożliwiła mu poznanie języka polskiego. Praca naukowa, którą rozpoczął w Wolsztynie, ukształtowała późniejsze losy badacza i zaprowadziła go na szczyty sławy naukowej uhonorowanej Nagrodą Nobla w 1905 r.

Trzeba pamiętać, że Koch pracując naukowo nad drobnoustrojami powodującymi choroby zakaźne był sam w swoim prowincjonalnym laboratorium. Konsultacje naukowe, dyskutowanie wyników, prezentacje, sukcesy i watpliwości były treścią jedynie korespondencji z innymi naukowcami z niemieckich uniwersytetów, w tym najbliżej położonego Uniwersytetu w Breslau (we Wrocławiu) ${ }^{39}$.

Cytując za dr. Below z Hanoweru (1908):

Wolsztyn i Poznańskie zyskały dzięki Kochowi honor miejsca, z którego wyszła międzynarodowa sława, przynosząc im dumę na wszystkie czasy ${ }^{40}$. Robert Koch należy do grupy wielkich uczonych, Europejczyków z polskiej ziemi. Od XIX wieku jego imię jest znane całemu światu ${ }^{41}$.

38 M. Adamczak, Wolsztyn w XIX w. red. A. Prządka, Wolsztyn, 2012.

39 J. Thorwald, Stulecie chirurgów, Kraków 2008, s. 375-402.

40 R. K. Meissner, Wolsztyńskie lata Roberta Kocha ze szczególnym uwzględnieniem badań etiologii zachorowań na waglik, [w:] Robert Koch Etiologia zachorowań na waglik, Poznań - Wolsztyn 1996, s. 17-30.

41 A. Rouillon, Who is the man who discovered the Tubercle Bacillus? "Bulletin of International Union of Tuberculosis and Lung Disease" 1990/1991, supl. 66, s. 71-76. 
Należy przypomnieć, że w ostatniej ćwierci XIX w. (lata 1876-1899) większość gatunków bakterii patogennych została wykryta i opisana przez niemieckich badaczy, pracujących samodzielnie bądź w kooperacji z Francuzami, Belgami, Anglikami. We wszystkich odkryciach rola Kocha była wiodąca ${ }^{42}$.

Pobyt w Wielkopolsce był niezwykle ważnym etapem w życiu Roberta Kocha. Tutaj miał swoje pierwsze własne laboratorium badawcze, pierwszy własny mikroskop, tutaj rozpoczęła się jego praca naukowa, pierwsze odkrycia, potem uznane za wiekopomne, wszystko to miało swój poczatek w Wolsztynie przy ul. Biała Góra 12. Obecnie w oficynie budynku, w którym mieszkał, mieści się Stowarzyszenie Naukowe i Fundacja imienia Roberta Kocha. Stowarzyszenie od chwili założenia w 1995 r. organizuje sympozja naukowe i konferencje, upowszechnia wiedzę o życiu i działalności wielkiego uczonego, współpracuje z Instytutem Roberta Kocha w Berlinie.

\section{Zakończenie}

Robert Koch umarł nagle na atak serca 27 maja 1910 r. Jego ciało zostało skremowane, a prochy zdeponowane w Instytucie w Berlinie, któremu w 1912 r. dla uczczenia 30. rocznicy odkrycia prątków gruźlicy dodano nazwisko wielkiego odkrywcy. W Japonii w 1910 r. japoński kolega i współpracownik Kocha, światowej sławy naukowiec prof. Shibasaburo Kitasato (1853-1931), dla wyrażenia głębokiego żalu po jego śmierci zbudował w pobliżu National Institute of Infectious Diseases sanktuarium jego imienia „Koch Shrine”, umieszczając w nim kosmyk włosów Roberta Kocha na pamiątkę wielkiej przyjaźni. Po śmierci Kitasato i nieszczęśliwym pożarze pierwszego sanktuarium japońscy przyjaciele połączyli oba sanktuaria w jedno, które obecnie nosi nazwę „Koch-Kitasato Shrine”.

Po śmierci Kocha najpiękniej wyrażono żal z powodu straty znakomitego uczonego w „Lekarskim Tygodniku Petersburskim” tymi słowami: „Każdy pomnik jest bardziej przemijający niż dzieło jego własnego umysłu. Jego dzieło dotyczy całej ludzkości i poszczególnego człowieka" ${ }^{\prime 3}$.

\section{Wykaz literatury}

1. Accocella G., Clinical pharmacokinetics of rifampicin, "Clinical Pharmacokinetics" 1978, 3, s. $108-127$.

2. Adamczak M., Wolsztyn w XIX w., red. A. Prządka, Wolsztyn 2012.

3. Ayvazian F. L., History of tuberculosis, [w:] Tuberculosis: A Comprehensive International Approach, red. L. B. Reichman, E. S. Hershfield, New York 1993, s. 1-20.

4. Blevins S. M., Bronze M.S., Robert Koch and the "golden age" of bacteriology, "International Journal of Infectious Diseases" 2010, 14, s.e744-e751.

5. Comroe, J. H. Jr., Pay dirt: the story of streptomycin. Part II. Feldman and Hinshaw: Lehmann, "American Review of Respiratory Diseases" 1978, s. 957-968.

${ }^{42}$ Z. Zwolska, Stulecie mikrobiologicznej diagnostyki gruźlicy w Polsce, [w:] Towarzystwa naukowe w Polsce, dziedzictwo, kultura, nauka, trwanie, t. 2, Warszawa 2013, s. 307-321.

43 R. Talewski, Robert Koch 11.XII.1843 - 27.V.1910, „Pneumonologia Polska” 1982, 50 (11), s. 553-555. 
6. Dalmia N., Ramsay A. J., Prime-boost approaches to tuberculosis vaccine development, "Expert Review of Vaccines" 2012, 14, s. 1221-1233.

7. Daniel T. M., Hermann Brehmer and the origins of tuberculosis sanatoria, "International Journal of Tuberculosis and Lung Diseases" 2011, 15, s. 161-162.

8. Diel R., Vandeputte J., de Vries G, Stillo J., Wanlin M., Nienhaus A., Costs of tuberculosis disease in the European Union: a systematic analysis and cost calculation, "European Respiratory Journal" 2014, 43, s. 554-565. DOI: $10.1183 / 09031936.00079413$

9. Dudnyk A., Rzhepishevska O., Kutsyna G., Lange K., Multidrug-resistant tuberculosis in Ukraine at the time of military conflict, "International Journal of Tuberculosis and Lung Diseases" 2015, 19 (4), s. 492496.

10. European Centre for Disease Prevention and Control/WHO Regional Office for Europe. Tuberculosis surveillance and monitoring in Europe, Stockholm, Sweden: ECDC, 2016.

11. Honap T. P., Pfister L. A., Housman G., Mills S., Tarara R. P. i in., Mycobacterium leprae genomes from naturally infected nonhuman primates. 2018

12. Kielanowski T., Elementy etiopatologii gruźlicy człowieka, Warszawa 1965.

13. Koch R., Etiologia zachorowań na waglik (1876), Poznań - Wolsztyn 1996.

14. Koch R., The Nobel lecture on how the fight against tuberculosis now stands, "Lancet" 1906, 1, s. 1449-1451.

15. Kochman K., Wynalazca z przypadku. http:/ / www.naukaonline.pl/nasze-teksty/nauki-biologiczne/ item/108-wynalazca-z-przypadku.

16. Lee R. H., Hurdle J. G., Liu J., Bruhn D. F., Matt T., Spectinamides: a new class of semisynthetic antituberculosis agents that overcome native drug efflux, "Natural Medicines" 2014, s. 152-158.

17. Madkour M. M., Al.- Otaibi K. E., Al-Swailen R., Historical aspects of tuberculosis, [w:] Tuberculosis, pod red. M. M. Madkur, Berlin - Heidelberg 2004.

18. Mann T., Czarodziejska góra, Warszawa 1972.

19. Meissner R. K., Wolsztyńskie lata Roberta Kocha ze szczególnym uwzględnieniem badań etiologii zachorowań na waglik, [w:] Robert Koch Etiologia zachorowań na waglik, Poznań - Wolsztyn 1996.

20. Migała M., Rys historyczny rozwoju leczenia gruźlicy na Górnym Ślasku w drugiej połowie XIX i pierwszej połowie XX wieku, [w:] Walka z gruźlica u ludzi i zwierzat w Polsce, pod red. H. Dusińska, Z. Zwolska, Warszawa 2012.

21. Rouillon A., Who is the man who discovered the Tubercle Bacillus? "Bulletin of International Union of Tuberculosis and Lung Diseases" 1990/1991, supl. 66, s. 71-76.

22. Satta G., Atzeni A1, McHugh T.D., Mycobacterium tuberculosis and whole genome sequencing: a practical guide and online tools available for the clinical microbiologist, "Clinical Microbiology and Infection" 2017, 23, s. 69-72.

23. Sontag S., Choroba jako metafora, Warszawa 1999.

24. Talewski R., Robert Koch 11.XII.1843 - 27.V.1910, "Pneumatologia Polska" 1982, 50 (11), s. 553- 555.

25. Tanimura T., Jaramillo E., Weil D., Raviglione M., Lonnrath K., Financial burden for tuberculosis patients in low-and middle-income countries: a systematic review, "European Respiratory Journal" 2014, 43, s. $1763-1775$.

26. Thorwald J., Stulecie chirurgów, Kraków 2008, s. 375-402.

27. Urbanik M., Odkrycie Roentgena - pierwsze doniesienia prasowe, artykuty naukowe i podreczniki w Krakowie. „Przegląd Lekarski” 2013/70/5 s 359-365.

28. Usman M. M., Ismail S., Teoh T. C., Vaccine research and development: tuberculosis as a global health threat, "Central European Journal of Immunology" 2017, 42(2), s. 196-204. doi: 10.5114/ceji.2017.69362. Epub 2017 Aug 8.

29. Waksman S., Woodruff H. D., Actinomyces antibiotics, a new soil organism antagonistic to phatogenic and non-phatogenic bacteria, "Journal of Bacteriology" 1941, 42, s. 231-249.

30. World Health Organization. Global Tuberculosis report, 2015 WHO/HTM/TB/2015.22. Geneva, 2015.

31. Yang H., Kruh-Garcia N. A., Dobos K. M., Purified protein derivatives of tuberculin--past, present, and future. FEMS Immunol Med Microbiol. 2012 Dec;66(3):273-80.

32. Zaorska B., Ich mizeria tułacza z gruźlica w tle, Warszawa 1998.

33. Zaorska B., Odnaleziony zbiór kart ambulatoryjnych z roku 1849 i 1850 dotyczqcy grupy uchodźców polskich w Anglii, „Archiwum Historii i Filozofii Medycyny" 1997, s. 211-218.

34. Zaorska B., Śladami lekarzy - polskich uchodźców popowstaniowych w XIX wieku. Warszawa 1996.

35. Zwolska Z., Historia rozwoju mikrobiologicznej diagnostyki gruźlicy w Polsce, [w:] Rudka 100 lat w stużbie zdrowia, red. H. Dusińska, J. B. Gliński, M. Zambrzycka, Warszawa 2008, 22-34. 
36. Zwolska Z., Improving treatment outcomes for tuberculosis, "Journal of Bioequivalence Availability" 2017, s. 442-446.

37. Zwolska Z., Koch i jego dokonania - rys historyczny, „Postępy Mikrobiologii” 2010, s. 139-150.

38. Zwolska Z., Robert Koch twórca bakteriologii chorób zakaźnych, Gdańsk 2006.

39. Zwolska Z., Stulecie mikrobiologicznej diagnostyki gruźlicy w Polsce, [w:] Towarzystwa naukowe w Polsce, dziedzictwo, kultura, nauka, trwanie, t. 2, Warszawa 2013, s. 307-321.

40. Zwolska Z., Augustynowicz-Kopeć E., Trą jedna z zapomnianych chorób tropikalnych, „Postępy Higieny i Medycyny Doświadczalnej" 2017, 71, s. 69-77.

41. Zwolska-Kwiek Z., Ryfampicyna, Warszawa 1989, s. 100.

\section{Wykaz stron internetowych:}

1. http://www.history.com/this-day-in-history/penicillin-discovered

2. http:// www.journal.doc.art.pl/pdf14/artbasedresearch_luczak_art_and_documentation14.pdf

3. https:// www.nobelprize.org/nobel_prizes/physics/laureates/1901/rontgen-bio.html

4. http:/ / thebiomedicalscientist.net/science/big-story-petri-dish

5. www.thelancet.com/journals/lancet/article/PIIS0140 